\title{
IS MARITIME ENGLISH THE KEY IN SOLVING COMMUNICATION PROBLEMS WITHIN MULTINATIONAL CREWS? Raluca APOSTOL-MATES*, Alina BARBU**
}

\author{
*“Mircea cel Bătrân" Naval Academy, Constanța, **Maritime University, Constanța, Romania \\ ucamates@yahoo.com
}

\begin{abstract}
In the present world of international shipping, where multinational and multicultural crews are the most common, communication between those on board and between ship and shore is increasingly important.

The present paper intention is to reveal, pinpoint and analyze different problems that emerge from the heterogeneous crews' failure in communication. The basis of the analysis is given by a number of maritime accident reports in which lack of communication between crew members played a paramount role in the causal chain. The paper also intends to put an accent on the benefits of maritime English.
\end{abstract}

\section{Keywords: communication, accidents, human error}

\section{Introduction}

Our daily lives are possessed by taking risks and making mistakes - it is in our human nature. Some mistakes can be rectified in due time without causing any harm to ourselves or to other people or property, some cannot, and these usually have disastrous consequences.

Accidents investigations and reports have the primary role of preventing casulties and property loss through the objective pinpoint of the causes that are more likely to trigger an incident or manifest during an accident. Recommendations from accident investigation reports can have a huge impact on maritime industry leading to the development of more regulations, or updating existent ones. To have such an impact, a huge tragedy may have occured as a result of a mishappening which had never been taken into consideration by the existing procedures. Unfortunately, some reliable sources[1] [2] found out that only very few countries analyze maritime accidents and only an average of $15 \%$ of maritime accidents in a country is analyzed. Small accidents should be analyzed in order to minimize the incidency of being repeated with more serious consequences. By analyzing incidents or small accidents companies could improve their ships' safety management systems by the means of increased training/drills or by reviewing its safety procedures. In the maritime context, the most important thing is to learn from our mistakes and from the mistakes of others.

\section{Communication challenges}

Multicultural crews have been the basis of the shipping industry in the last 50 years. Many shipowners preferred to hire seamen from poor countries working for little money instead of their own nationalities. If in the early stages only OS and AS positions were filled with South-East Asian nationalities, today's trend is to also have $3^{\text {rd }}$ and $2^{\text {nd }}$ mates from those countries. It is undeniable that economic recession rooted the above mentioned trend, but it also raised problems in communication. 
Unfortunately, ship owners and shipping companies often seem to overlook basic issues like the training of the seafarers. Employing seamen from different nationalities brings different standards of training onboard ship, both for what Maritime English is concerned in terms of SMCP, and for the level of knowledge regarding STCW, SOLAS, MARPOL. Along with this, cultural attributes which are brought by these seamen give a more complex extent to the use of the Maritime Language onboard.

\subsection{Maritime communication}

Communication is the act of transferring information through verbal messages, written word or non-verbal signals.

As it is well known, maritime communication manifests itself on three levels: onboard communication, ship-to-ship communication and ship-to-shore communication.

Onboard communication takes place between the deck crew - wheel commands, landmarks, navigation guidance, ship position, general info, problems; the engine crew - mechanical commands, general info, problems; and between the above mentioned - engine commands, equipment, ship's performance, problems.

To eliminate the problem of multiculturalism in onboard communication, for relaying standard commands or reporting standard informations, IMO has established in 2001 a series of Standard Marine Communication Phrases (SMCP).

Ship-to-ship communication takes place for: transmitting navigation info, transmitting weather info, transmitting warnings or problems, or requesting help.

Ship-to-shore communication takes place for: transmitting navigation info, transmitting weather info, transmitting warnings or problems, requesting help, requesting permission.

The International Convention for the Safety of Life at Sea (SOLAS74) requires companies to ensure onboard all ships adequate means in place for effective oral communication and communication between ship and shore based authorities. The Convention on Standards of Training Certification and Watchkeeping (STCW95) stresses that effective communication must prevail onboard at all times.

\subsection{Official Reports illustrating poor language usage}

Here are some examples of language related problems that have been highlighted in accident investigation reports:

1. ATSB Marine Safety Investigation Report No. 200 - Grounding of the Astor on 26 February 2004

The master did not accept the pilot's advice after the ship left the berth.

Communications on the bridge were in a language the pilot was not able to understand.

The master did not present an outward passage plan to any of those present on the bridge at the time of departure. [9]

2. MAIB report on the grounding of the Jackie Moon on 1 September 2004

The Coastguard had difficulty understanding the content of the transmissions from the ship because of the poor quality of the spoken English. The Ukrainian crew were expected to speak English. The technical manager had no concerns about the competency of the master before the accident, although he considered his standard of English could have been better. [10]

3. US Coastguard report on the Explosion and Sinking of the Bow Mariner on 28 February 2004

Although the official language of the crew was English, the captain Kavouras and chief engineer Athanasiou were talking in Greek while the entire crew was preparing to abandon ship. [11]

4. ATSB Marine Safety Investigation Report No.212 - Crew member burnt on board ship off Carnarvon, Western Australia

- RCC Australia attempted to get medical advice to Hui Shun Hai's master, but language difficulties prevented this from happening. [12]

\subsection{Sewol case}


The sinking of the MV Sewol (Korea) occurred on 16 April 2014 en route to Jeju from Incheon. The South Korean ferry capsized while carrying 476 people (officially announced number, but actually unknown), mostly secondary school students from Danwon High School (Ansan City). The main cause of the accident was a sharp turn of 5 degrees on the starboard side followed by a quick turn of 5 degrees on the port side, causing the ship to tilt. Even the OOW had been instructed that the ship must not be steered by more than 4 degrees; the inexperienced $3^{\text {rd }}$ mate gave the helmsman the order that provoked the tragedy. Apparently, the ferry was carrying 3600 tons of cargo, despite a limit of 987 tons, cargo that unbalanced the ship during the manoeuvre. After the first order, the OOW gave another order in Korean, to balance the ship to port, but it was misheard as "turn the opposite way", a turn that caused the ship to tilt. Deadly mistakes were about to thread on. The chief engineer stopped the engines without asking the captain and ordered an evacuation of the engine room, causing the ferry to lose electric power and all control, drifting with the current. From the engine room, a sudden manoeuvre one one side followed by one on th opposite side may have been perceived as a standard manoeuvre when avoiding a collision. Without asking for details from deck, the chief engineer took a wrong decision. As the ferry was sinking, through the Public Address System the following message was issued:"Do not move. Just stay where you are. It's dangerous if you move, so just stay where you are". The message was issued without consulting the manual and it was continuosly given, even when the ferry crew was abandoning the ship.

Another mistake of the crew was the miscommunication with the shore; a distress signal was given 7 minutes after the ferry started sinking, but a passenger of the ferry called the national emergency service three minutes after the ferry started sinking, four minutes before the crew.

Even when the Coast Guard ordered the captain of the ferry to give lifejackets, the crew kept telling the passengers to stay in their rooms and not move.

During the sinking of the ship, that lasted two hours, the crew drank beers, abandoning the ship afterwards. The first persons who were rescued from the ferry were the captain, the chief engineer and the chief and second mates, approximately 40 minutes after the ship started sinking.

Only 172 people survived, out of 476. [3]

The main errors in communication were:

- the orders given by the OOW for the sudden and successive turns;

- the lack of consulting with the captain about the turns;

- the lack of consulting with the captain about turning off engines;

- the lack of communication with the shore about the situation of the ferry;

- the delay in sending the distress message;

- the order to stay in their cabins given to the passengers;

- the lack in communication and coordination with the rescue teams;

- the lack of communication with the passengers throughout the sinking.

The crew and its captain were charged with homicide (4 including the captain), fleeing and abandoning the $\operatorname{ship}(2)$ and negligence(9). The captain was sentenced to 36 years in prison, the chief engineer 30 years, and 13 othr crew members received from 5 to 20 years.

\section{Conclusions}

Even it is common knowledge that many shipping companies or ship owners do not take responsibility after an accident if language issues are marked out as the main cause of it, and even if language problems are not amongst the first causes in accidents reports, they are high-lighted as secondary cause or aggravating circumstances. The most important thing the shipping industry can do for its own sake is to employ trained seamen who have at least the abilities to understand English used in maritime environment if not the communication skills in Maritime English. 


\section{References}

[1] Jan Hork, Cultural and gender diversities affecting the ship/port interface, ISPIC, Bremen, 2008 at http://www.knowships.org/pdfs/Cultural-Sensitivities-3.pdf.

[2] IMO FSI 13/WP.2, 13th Session, Agenda Item 4, Casualty Statistics and Investigations, Report of the Working Group, FSI 13/14 Annex 1, Page 30), 10 March 2005.

[3] http://worldmaritimenews.com/archives/138897/cargo-overload-and-poor-managementled-to-sewol-tragedy/

[4] https://dvikan.no/ntnustudentserver/reports/MANAGING\%20THE\%20HUMAN\%20ELEMENT\%20IN\%20 MODERN\%20SHIP\%20DESIGN\%20AND\%20OPERATION.pdf

[5] http://www.imo.org/blast/blastDataHelper.asp?data_id=18000\&filename= InternationalSeminar.pdf

[6] http://gcaptain.com/sewol-becomes-100th-passenger-vessel-lost-since-2002/

[7] http://www.marifuture.org/Publications/Papers/improving_safety_at_sea_ and_ports_by_developing_standards_for_maritime_english.pdf

[8] https://www.gov.uk/government/uploads/system/uploads/attachment_data/ file/419923/MAIB_SafetyDigest_1-2015.pdf

[9] https://www.atsb.gov.au/publications/investigation_reports/2004/mair/mair200.aspx

[10] https://assets.digital.cabinet-office.gov.uk/media/547c70ae40f0b602440000c1/ Jackie Moon.pdf

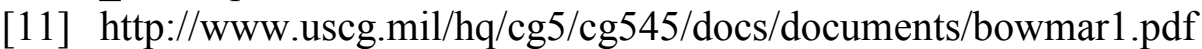

[12] http://atsb.gov.au/media/1364828/mair212_001.pdf 